\title{
Cultural significance determination as preliminary analysis in preserving urban historical area (Case study on municipality of Blitar, Indonesia)
}

\author{
Johannes Parlindungan Siregar ${ }^{1}$, Antariksa ${ }^{2}$ and Eddi Basuki Kurniawan ${ }^{3}$ \\ ${ }^{1,2,3}$ (Researcher and lecturer on University of Brawijaya)
}

\begin{abstract}
History is a cultural richness because through history, a nation has strong foundation in future development. Blitar is one of the Indonesia city that has history richness. In the past, this city linked directly with Indonesian independence movements as the home town of Indonesian Independence Proclaimer and as place of PETA rebellions. It is important that the historical value becomes consideration in determining appropriate preservation action for plan further development strategies on an historical area. This research uses 36 objects in form of building complexes and sculptures. Analysis techniques utilized in this research are factor analysis, multi-criteria evaluation, cluster analysis and t-test. Preliminary variables utilized in this research are cultural significance parameters called theoretical variables. These theoretical variables then were extracted using factor analysis in to 3 factors. The results of this research are the cultural signification level of every object and clustering of objects that form 6 cluster based on their cultural signification attributes. As the result using $t$-test, it was proved that development of clusters has relationship with cultural significance level of each objects, so the model proposed by cluster analysis then can be utilized to explain pattern of cultural significance attributes of each objects.
\end{abstract}

Keywords: - Cluster, Factor, Preservation, Urban History

\section{INTRODUCTION}

History can be assumed as part of cultural richness of a nation. Through history, a nation has memory and makes it as a firm basis for future. History also can develop identity and image of an area that manifested through historical build environment. Blitar is one of Indonesian city that has many memories about the battle of Indonesian Independence. Blitar is not only often associated with Indonesian Proclaimer, which is Soekarno, but also Blitar was a place of several activities that is a part of endeavor chain in Indonesian Independence. In the past, Blitar was also a training place of local army unit founded by Japanese namely Fatherland Defender (Pembela Tanah Air /PETA) and Indonesian Student Army (Tentara Republik Indonesia Pelajar / TRIP). In Indonesian history, rebellion of PETA in 1945 was an important incident whereas the Indonesian Flag Nation was first flied on a flag pole which is now namely Tugu Potlot. This independence movement can be investigated mainly through two segments, as follows:

- The Independence Proclaimer.

Blitar is well known as the city of Soekarno or city of Independence Proclaimer. This is because of Soekarno originally come from Blitar. Historical object inherited from him is a house called famously as Istana Gebang. Taufik, et al [1] described that it was 13rd February 1945 when some prominent figure of PETA leaded by Shodanco Supriyadi discussed with Soekarno in Istana Gebang about PETA rebellion plan. - Rebellion of PETA.

This rebellion was the biggest incident in history of Indonesian. This incident was centered in PETA base (now complex of SMKN 3 school building) and spread out to other regions.

Martokusumo [2] mentioned that identity making is crucial issue in urban conservation and revitalization. Concept of urban identity has close meaning with cultural significance and can be said that an urban object is feasible to be preserved reasonably because it is assumed as cultural heritage. Martokusumo [3] defines that generally this urban cultural heritage has a form of natural environment (water body, land and so on) and build environment (site, building group, urban structures, grave yard and so on). Preservation of these objects then undergo based on their cultural significance. According to ICOMOS [4], cultural significance is a concept which is helpful in identification, understanding and valuation characteristics that an object determined as valuable. These objects have cultural significance based on several parameters such as historical context, architecture, archeology, social / cultural contribution in society and engineering.

This research is a part of complex study about preservation of historical area in Blitar with focus on determination of cultural signification and tries to find historical potential of objects in the form of cultural significance as the preliminary research according to ICOMOS [4] and Indonesian Network for Heritage 
Conservation [5]. This research analyzes 36 historical objects using factor analysis, analytic hierarchy process (AHP), multi-criteria evaluation, cluster analysis and T-Test methods.

\section{RESEARCH METHOD}

This publication is a part of general research about preservation of historical area of Indonesian Independence in Blitar. The objects of this research are historical buildings and sculpture with age above 50 years as the main criteria (according to Indonesian National Act no.5/1992 about cultural heritage objects). Variables utilized in this research are factors of cultural significance from preceded study. Generally, analysis processes utilized in this research can be described as follows (Fig.1) :

1. Factor analysis (has undergone in preceded study). The objective of this analysis is to find factor of cultural significance from theoretical variable.

2. Multi-criteria evaluation. The objective of this analysis is to find cultural significance value of every object. Variable of this analysis are factors resulted from previous analysis. Two components that utilized in this analysis are weighted factors resulted from AHP techniques and score of factor components resulted from observation and historical content study.

3. Cluster analysis. This analysis is undergone to find object grouping pattern based on attribute of cultural signification factors. Variables of this analysis are standardized score of factor weighted scores.

4. T-test. This analysis is undergone to prove about the relationship between object clustering and level of cultural significance of every object.

Results of this analysis are groups of cultural significance attributes that valuable for understanding the past of Blitar and next analysis process (determination of preservation action).

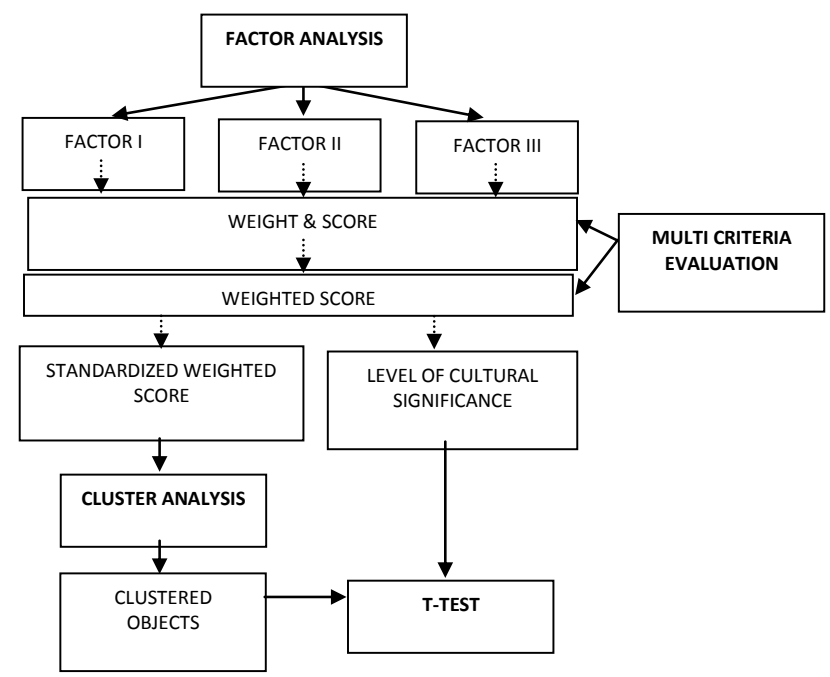

Figure 1. Analysis process

\section{A. Determination of Cultural Significance}

\section{RESUlTS AND DISCUSSION}

The factor of cultural significance is one of the most important parameter in research of urban historical area. This factor has main role as an aspect that explain why an urban object can be said as historical value. In the previous publication, Siregar, et al [6] utilized factors in determining cultural significance used several theoretical variables. These extracted factors are mentioned as follows:

- Factor I is interpreted as scientific potential includes some components such as historical value, age, social value and landmark.

- Factor II is interpreted as urban aesthetic potential and can be utilized as economic activities trigger (such as historical tourism). This factor consists of several components such as art value, uniqueness and social economy potential. Al-hagla [7] mentioned this potential as heritage trail that have direct approach to tourism. This concept is composited from tourists, locals and host place.

- Factor III is interpreted as utilization potential as its origin function or re-use and religious activities. This factor consists of several components such as functional and religious value. 
These factors need to be utilized in determining cultural signification, so they must be weighted by expert perception. Utilization of Analytical Hierarchy Process (AHP) method then resulted in weighted factors as follows:

- Factor I is weighted in $32,644 \%$

- Factor II is weighted in $30,190 \%$

- Factor III is weighted in $37,166 \%$

The last tool that must be prepared is valuing every objects based on cultural signification components that develop previous factor. This valuation has undergone against 36 objects (buildings and sculpture) using observation technique and historical-content analysis.

Determination of cultural signification then analyzed using multi-criteria evaluation as written in Ruiter and Sanders [8]. By utilization of this technique, the weighted variables (factor I, II and III) are valued by multiply the percentage of loading factor with factor weight and component score of every object. As result of this valuation are total weighted scores that interpreted as cultural significance value of every object with 4 categories: $0 \%-25 \%$ as D (the lowest), $25 \%-50 \%$ as C, $50 \%-75 \%$ as B and $75 \%-100 \%$ as A (the highest). From this analysis, then founded 6 objects in category A, 7 objects in category B and 23 objects in category C. Distribution of cultural signification level of every object can be overviewed in Appendix 1.

\section{B. Cultural Significance Attributes}

This research has specific context in scope of history that is historical substantial in relation to war of Indonesian Independence and focused in cultural significance related with rebellion of Indonesian PETA army in 14th of February 1945. This historical context then becomes clearer with the overviewed percentage of factor weighted scores of every object. This distribution can be seen in Fig. 2. Distribution of weighted scores then needs to be observed about their combination. Clusters of this distribution can explain characteristics of cultural significance values that attributed every historical object of this research. Ward's cluster analysis then utilized in clustering this distribution using SPSS. Before utilize SPSS, the weighted score of every factors need to be standardized by dividing it with weight value of every factor. This analysis resulted in 6 clusters of historical objects Appendix 1 and Appendix 2).

The accuracy of this model then supported by the correlation analysis (t-test) towards cultural signification value and cluster number which reject H0 (null hypothesis), concluding that there is relationship between cluster developed and cultural signification value (Appendix 3). So that, this clustering model can be utilized in explain pattern of clustered objects based on their attributes.

\section{First cluster}

This cluster is dominated by houses those of private houses and official house. Overall, standardized score distributions of this cluster have the lowest position among other clusters. These objects have cultural significance in $\mathrm{C}$ level that can be interpreted as moderately in history, architecture (art) and function. From Fig. 2 , we can overview that this cluster has the lowest standardized score of factor II compared with other clusters. This distribution can be interpreted that objects of this cluster have very little or may be neither economical potential because of their primary function as private house nor architectural uniqueness. The absence of architectural uniqueness cannot be driven so far to give prosperity of urban historical tourism or other activities that has economic value. The highest distribution of standardized score of this cluster is factor III that can be interpreted as functional value of the objects. As previously stated, this cluster consists of houses that permanently functioned as dwelling units. However, still this standardized score distribution is positioned below of 0.5 or $50 \%$. It can be concluded that conservation decisions of this cluster come only from its functional value and very little interest in historical or architectural value.

\section{Second cluster}

This cluster is dominated by houses those of private houses and one unit of official house and junior high school campus. Standardized score distributions of this cluster have the middle position among the other clusters with cultural significance in $\mathrm{C}$ level. Compared to the previous cluster, this second cluster has higher distribution of factor II standardized score that have the same average with factor I. The architectural and aesthetic value of the objects are characterized by unique design of private houses and treated environment that can give prosperity of urban historical or environmental tourism. Like the previous cluster, factor III has the highest distribution whereas functional value as dominant basis to decide suitable conservation actions of its objects.

\section{Third cluster}

This cluster consists of an ex-warehouse and a vocational senior high school. This cluster has distinctive pattern about distribution of factor II. This factor has the highest rate among the other factor that can 
be interpreted as domination of aesthetic value (Fig. 2). This value indicates that the two objects have prominent architectural uniqueness and can help in development of sense of place of this area. Although the same cluster, the two objects have different cultural significance level that of $\mathrm{C}$ (ex-warehouse) and B (vocational high school of St .Yusup).

\section{Fourth cluster}

This cluster consists of 5 objects (4 private houses and 1 electric house). All of these objects have C level of cultural significance. Factor II is the most dominant value and factor I is the least in average. Compared to the other clusters, this cluster has the lowest factor I value in average that can be interpreted as the least historical context. Among the objects of this cluster, private house labeled AY05 has distinctive aesthetic value with its colonial architecture style (over 0.5) but has a severe physical condition. From these facts, it can be concluded that objects of this cluster need physical rehabilitation in maximize their aesthetic potentials in developing better environmental sense of place.

\section{Fifth cluster}

This cluster consists of 7 objects ( 4 school complexes, 2 churches and 1 monastery). The objects of this cluster have cultural significance level in B (5 objects) and A (2 objects). Overall, factor I have the lowest distribution whereas 5 objects have points below 0.5 . It indicates that this cluster has low historical context. Factor III has the highest distribution that can be interpreted that objects of this cluster have regular function as schools and religious facilities. Factor II has the middle distribution level in average but in high value compared with previous 4 clusters, indicates that the objects of this cluster has high aesthetic value (over 0.5) because of their maintained physical condition. These well preserved objects then can be contributed in historical tourism or urban education of this city.

\section{Sixth cluster}

This cluster has the best distribution of factor standardized scores with high cultural significance levels (3 objects have A in cultural significance level and other B). It consists of 4 objects with the highest level of factor I. This score distribution can be interpreted that buildings of this cluster are the most important objects in historical context of Blitar. Factor II that of aesthetic value has lowest distribution among other factors, excepts in object labeled SA03 that has perfect aesthetic value that of 1,00. Factor III that labeled function and physical condition value has middle distribution level, indicates that several objects need maintenance program to optimize historical potentials of these objects. Object which is labelled SS08 consist of 71 buildings whereas 21 buildings have high historical value as described in Afandi, Antariksa and Hariyani [9]. Generally, historical buildings of this complex are well maintained and have original architectural character.

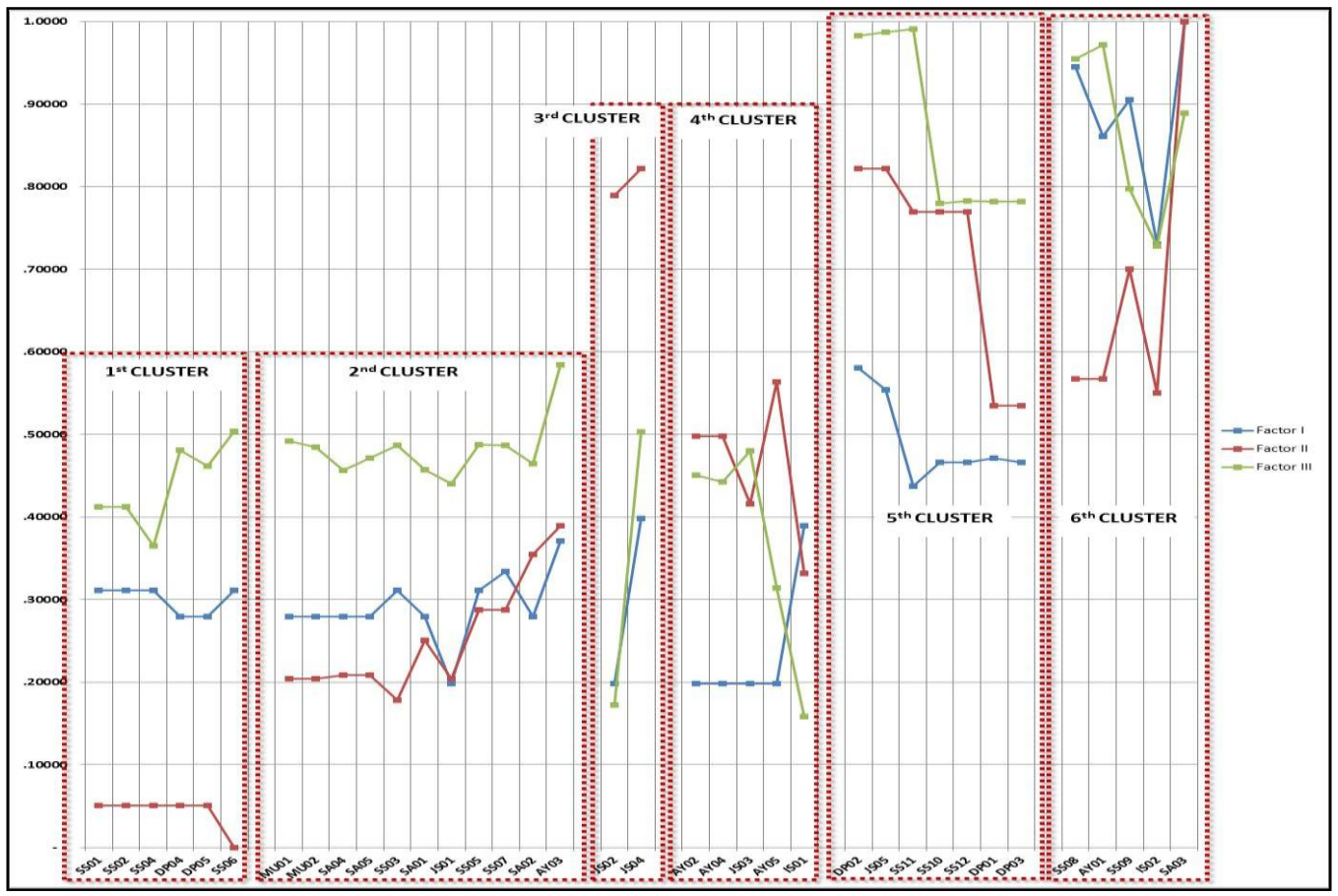

Figure 2. Distribution of standardized score of factors 
From these cluster we can obviously comprehend that cultural significance attributes have major role in understanding the past. Adeniran and Akinlabi [10] stated that this effort can help us in giving meaning to the present. Cultural significance can distinguish value of every historical object. As Avrami, Mason and Torre [11] mentioned, value that adhered with these historical objects then make them can be categorized as heritage and appropriate to be preserved.

\section{CONCLUSION}

There are 3 important parameters in determining cultural significance of historical objects in Blitar city that of education and historical context (factor I), aesthetic value and economical value (factor II) and functional value (factor III). Based on these factors, then it can be analyzed that objects of this research can be distributed in 6 clusters that characterized standardized score distribution of the 3 factors. These clusters can be explained as follows:

- First cluster is characterized by the middle cultural significance value that need stable maintenance and utilization because of their low aesthetic value and high function / utilization value.

- Second cluster is characterized by the middle cultural significance that need stable maintenance and utilization but with better aesthetic value (factor II) than the first cluster.

- Third cluster is characterized by the middle cultural significance that need stable maintenance and utilization but with high aesthetic value (factor II) that could be a potential of sense of place.

- Fourth cluster is characterized by the middle cultural significance that needs more maintenance and utilization with moderate aesthetic value (factor II).

- Fifth cluster is characterized by the high cultural significance, although factor I has the lowest position. However, overall have potential in environmental aesthetic and utilization.

- Sixth cluster is characterized by the highest cultural significance that need more maintenance and utilization. Although it has low distribution of factor II (aesthetic) compared to the other factors but this cluster consists of the most important objects in history context of Indonesian Independence. urban heritage.

These clusters then can be comprehended as value that makes them appropirate to be preserved as

\section{Acknowledgement}

We would thank to our Dean and colleagues in Department of Urban and Regional Planning, Faculty of Engineering, University of Brawijaya for materials and support in this research.

\section{REFERENCES}

[1] Taufik, et al, History of Blitar (Government of Blitar Municipality, 2008).

[2] Martokusumo, Urban heritage conservation in Indonesia, Proc in The Indonesian city revisited, Institute of Social and Cultural Studies, Faculty of Social and Behavioural Sciences, Rijksuniversiteit Leiden,The Netherlands, 6-8 December, 2000.

[3] Martokusumo, Conservation of urban environment (ITB Press, Bandung. 2005)

[4] ICOMOS. The burra charter (Australia ICOMOS incorporated 2000, ISBN 0957852800, 1999)

[5] Indonesian network for heritage conservation and ICOMOS Indonesia, Indonesia charter for heritage conservation (Center for heritage conservation, department of architecture and planning, Gadjah Mada University, Yogyakarta, Indonesia, 2003)

[6] Siregar, et al. 2010, Cultural significance factors determination of indonesian independence historical area in Blitar city, Proc national seminar of magister and doctoral program, engineering faculty, University of Brawijaya, Indonesia, 2010.

[7] Al-hagla, Sustainable urban development in historical areas using the tourist trail approach, Elsevier Cities Journal 27 (2010), 234248.

[8] Ruiters and Sanders, Physical planning: policies, methods and techniques (Faculty of civil engineering, Delft University of Technology, The Netherlands, 1998)

[9] Afandi, Antariksa and Hariyani, Preservation of PETA headquarter in Blitar city, Graduate theses, University of Brawijaya, 2008

[10] Adeniran and Akinlabi, Perceptions on cultural significance and heritage conservation: a case study of Sussan Wenger's building, Osogbo, Nigeria, African Journal of History and Culture Vol. 3(5), pp. 73-88, June 2011

[11] Avrami, Mason and Torre, Value and heritage consevation, research report., The Getty Conservation Institute, Los Angeles, 2009 
Cultural significance determination as preliminary analysis in preserving urban historical area

\begin{tabular}{|c|c|c|c|c|c|c|c|}
\hline \multirow{2}{*}{$\underset{\text { RS }}{\text { KLUSTE }}$} & \multirow[b]{2}{*}{ OBJECTS } & \multirow{2}{*}{$\begin{array}{l}\text { OBJE } \\
\text { CT } \\
\text { CODE }\end{array}$} & \multicolumn{3}{|c|}{ STANDARDIZED SCORE } & \multirow{2}{*}{$\begin{array}{c}\text { SCORE of } \\
\text { CULTURAL } \\
\text { SIGNIFICAN } \\
\text { CE }\end{array}$} & \multirow{2}{*}{$\begin{array}{c}\text { LEVEL of } \\
\text { CULTUR.AL } \\
\text { SIGNIFICANC } \\
\text { E }\end{array}$} \\
\hline & & & $\begin{array}{c}\text { Factor } \\
\text { I }\end{array}$ & $\begin{array}{c}\text { Factor } \\
\text { II }\end{array}$ & $\begin{array}{l}\text { Factor } \\
\text { III } \\
\end{array}$ & & \\
\hline \multirow{6}{*}{ I } & Private house & SSO1 & 0.311 & 0.051 & 0.413 & 0.153 & C \\
\hline & Private house & $\mathrm{SSO}_{2}$ & 0.311 & 0.051 & 0.413 & 0.153 & C \\
\hline & Private house & SSO4 & 0.311 & 0.051 & 0.365 & 0.136 & C \\
\hline & Private house & DP04 & 0.280 & 0.051 & 0.481 & 0.179 & C \\
\hline & Private house & DP05 & 0.280 & 0.051 & 0.462 & 0.172 & C \\
\hline & Official house of visemajor & SS06 & 0.311 & - & 0.504 & 0.187 & $\mathrm{C}$ \\
\hline \multirow{11}{*}{ II } & Private house & MUO1 & 0.280 & 0.204 & 0.492 & 0.183 & C \\
\hline & Private house & MUO2 & 0.280 & 0.204 & 0.485 & 0.180 & C \\
\hline & Private house & $\mathrm{SAO} 04$ & 0.280 & 0.209 & 0.457 & 0.170 & c \\
\hline & Private house & SAO5 & 0.280 & 0.209 & 0.471 & 0.175 & C \\
\hline & Private house & SS03 & 0.311 & 0.178 & 0.487 & 0.181 & C \\
\hline & Private house & SAO1 & 0.280 & 0.251 & 0.458 & 0.170 & C \\
\hline & Private house & JSO1 & 0.198 & 0.204 & 0.440 & 0.164 & C \\
\hline & Private house & SS05 & 0.311 & 0.288 & 0.488 & 0.181 & C \\
\hline & Official house of army chief & Sso 7 & 0.334 & 0.288 & 0.487 & 0.181 & C \\
\hline & Private house & $\mathrm{SA} 02$ & 0.280 & 0.355 & 0.465 & 0.173 & C \\
\hline & $\begin{array}{l}\text { Complex of state junior high } \\
\text { school }\end{array}$ & AY03 & 0.371 & 0.390 & 0.585 & 0.217 & $c$ \\
\hline \multirow[t]{2}{*}{ III } & Ex warehous a & $\mathrm{JS} 02$ & 0.198 & 0.790 & 0.173 & 0.064 & C \\
\hline & $\begin{array}{l}\text { Vocational high school of St } \\
\text { Yusur. }\end{array}$ & $\mathrm{JSO} 4$ & 0.399 & 0.822 & 0.504 & 0.187 & $\mathrm{~B}$ \\
\hline \multirow{5}{*}{ IV } & Private house & $\mathrm{AYO} 2$ & 0.198 & 0.498 & 0.451 & 0.168 & C \\
\hline & Private house & AYO4 & 0.198 & 0.498 & 0.443 & 0.164 & C \\
\hline & Private house & $\mathrm{JS} 03$ & 0.198 & 0.416 & 0.480 & 0.179 & c \\
\hline & Private house & AYos & 0.198 & 0.564 & 0.314 & 0.117 & $\mathrm{C}$ \\
\hline & Electric house & ISO1 & 0.390 & 0.332 & 0.158 & 0.059 & $\mathrm{C}$ \\
\hline \multirow{7}{*}{$\mathrm{V}$} & Catholic church of St Yuㅗ고모. & $\mathrm{DPO} 2$ & 0.581 & 0.822 & 0.983 & 0.365 & A \\
\hline & Protestant church of GPIB & JSO5 & 0.554 & 0.822 & 0.987 & 0.367 & A \\
\hline & $\begin{array}{l}\text { Catholic monastery of Holy } \\
\text { Spirit }\end{array}$ & SS11 & 0.437 & 0.769 & 0.991 & 0.368 & B \\
\hline & $\begin{array}{l}\text { Complex of St Maria Catholic } \\
\text { elementary school }\end{array}$ & SS10 & 0.466 & 0.769 & 0.780 & 0.290 & $B$ \\
\hline & $\begin{array}{l}\text { Complex of St Maria Catholic } \\
\text { kindergarten }\end{array}$ & SS12 & 0.466 & 0.769 & 0.783 & 0.291 & $B$ \\
\hline & $\begin{array}{l}\text { Complex of Yohan Gabrial } \\
\text { Catholic junior high school }\end{array}$ & DP01 & 0.472 & 0.535 & 0.782 & 0.291 & B \\
\hline & $\begin{array}{l}\text { Complex of Dip onegere } \\
\text { Catholic Senior high school }\end{array}$ & DP03 & 0.466 & 0.535 & 0.782 & 0.291 & $\mathrm{~B}$ \\
\hline \multirow{5}{*}{ VI } & $\begin{array}{l}\text { Complex of Independence } \\
\text { Pigner office, SMIKN } 3 \text {, SMPN } \\
3 \text {, SMPN } 5 \text { and SMPN } 6\end{array}$ & SSO8 & 0.945 & 0.568 & 0.955 & 0.355 & A \\
\hline & $\begin{array}{l}\text { Complex of state senior high } \\
\text { school }\end{array}$ & AY01 & 0.861 & 0.568 & 0.972 & 0.361 & A \\
\hline & Tug Potlet & S\$09 & 0.905 & 0.700 & 0.798 & 0.297 & $A$ \\
\hline & $\begin{array}{l}\text { Campus III of Malang } \\
\text { University }\end{array}$ & ISO2 & 0.730 & 0.550 & 0.728 & 0.271 & B \\
\hline & Istana Gebang & $\mathrm{SA} 03$ & 1.000 & 1.000 & 0.889 & 0.330 & A \\
\hline
\end{tabular}


Cultural significance determination as preliminary analysis in preserving urban historical area

Appendix 2

Dendogram of cluster analysis

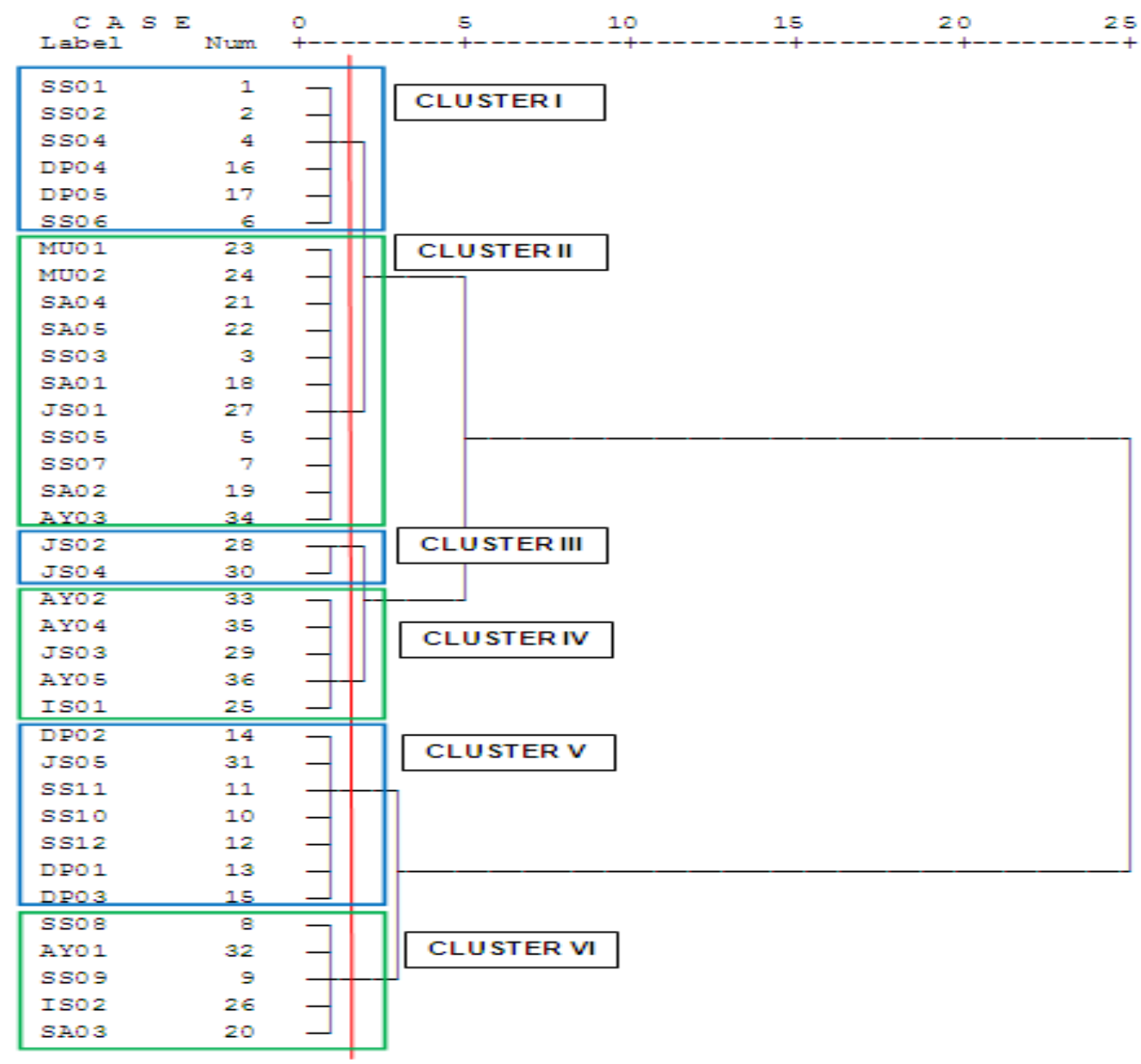

\section{Appendix 3}

\section{Result of t-test}

\begin{tabular}{|c|c|c|c|c|c|c|c|c|c|c|}
\hline \multicolumn{11}{|c|}{ Independent Samples Test } \\
\hline & & \multicolumn{2}{|c|}{$\begin{array}{c}\text { Levene's Test for } \\
\text { Equality of Variances }\end{array}$} & \multicolumn{7}{|c|}{$\mathrm{t}$-test for Equality of Means } \\
\hline & & \multirow[b]{2}{*}{$\mathrm{F}$} & \multirow[b]{2}{*}{ Siq. } & \multirow[b]{2}{*}{ t } & \multirow[b]{2}{*}{ df } & \multirow[b]{2}{*}{ Sig. (2-tailed) } & \multirow{2}{*}{$\begin{array}{c}\text { Mean } \\
\text { Difference }\end{array}$} & \multirow{2}{*}{$\begin{array}{l}\text { Std. Error } \\
\text { Difference }\end{array}$} & \multicolumn{2}{|c|}{$\begin{array}{l}95 \% \text { Confidence } \\
\text { Interval of the } \\
\text { Difference }\end{array}$} \\
\hline & & & & & & & & & Lower & Upper \\
\hline CLUSTER & $\begin{array}{l}\text { Equal variances } \\
\text { assumed }\end{array}$ & 2.455 & .126 & 5.985 & 34 & .000 & 2.50000 & .41770 & 1.65113 & 3.34887 \\
\hline & $\begin{array}{l}\text { Equal variances } \\
\text { not assumed }\end{array}$ & & & 5.985 & 31.357 & .000 & 2.50000 & .41770 & 1.64849 & 3.35151 \\
\hline
\end{tabular}

T-test $=5.985$

T table $(0.05,34)=2.0322$

T-test $>\mathrm{T}$ table, so $\mathrm{H} 0$ rejected and there is relationship between variables (formed clusters and cultural significance level) 